\title{
RECENZIJA
}

\section{O SMERNICAH ZA PRIHODNOST NA PODROČJU STRATEŠKEGA KOMUNICIRANJA}

Novembra lani je International Journal of Strategic Communication, ki ga izdaja Routledge, Taylor \& Francis Group, izdal posebno tematsko številko z naslovom Future directions of strategic communication.

Kot $\mathrm{v}$ uvodu razlagajo uredniki Howard Nothhaft $\mathrm{z}$ oddelka za strateško komuniciranje na univerzi v Helsingborgu na Švedskem, Kelly Page Werder z univerze v južni Floridi v ZDA, Dejan Verčič z Univerze v Ljubljani in Ansgar Zerfass iz norveške poslovne šole v Oslu, je ideja za posebno številko nastala na predkonferenci International Communication Association, 67th Annual Conference, v San Diegu v Kaliforniji maja 2017. Zbralo se je 42 akademikov iz 14 držav in predstavilo 21 prispevkov. V posebni številki so uredniki zbrali deset odličnih člankov. Z njimi so želeli odgovoriti na nekaj pomembnih vprašanj. Ugotovili so, da še vedno ni univerzalnega razumevanja stebrov, na katerih temelji strateško komuniciranje. Vprašali so se, kaj sta bistvena perspektiva in prispevek $\mathrm{k}$ temu, ali uporabljajo ustrezne strategije in koncepte komuniciranja, kaj se lahko naučijo iz nedavnih razprav v strateškem menedžmentu in strateških povezavah, kako lahko empirične študije prispevajo k razpravam in kako se področje razvija $\mathrm{v}$ različnih delih sveta.

Uredniki $\mathrm{v}$ prvem sklopu $\mathrm{z}$ naslovom The emergence of a paradigm $\mathrm{v}$ dveh člankih obljubljajo interdisciplinarni pogled znotraj akademskega strateškega komuniciranja, ki bo trdneje opredelil njegov namen, ki je do zdaj manjkal.

V drugem sklopu z naslovom Conceptual foundations of strategic communication se zvrstijo štirje članki šestih avtorjev, ki so predvsem teoretični in so poleg strateškega komuniciranja povezani še z drugimi področji. 
Tretji sklop Expanding the body of knowledge sestavljajo trije članki osmih avtorjev. Osredotočeni so na najpomembnejše koncepte, identiteto in funkcijo osnovne discipline.

Zadnji sklop z naslovom Future directions of strategic communication ima le en članek, ki so ga napisali vsi štirje uredniki in bo najverjetneje naletel na največ pozornosti, posebej tistih, ki se ukvarjajo s področjem strateškega komuniciranja na varnostnem, obrambnem in vojaškem področju. Avtorji nas uvedejo v pojem in zgodovino strateškega komuniciranja, ki sta na različnih področjih zelo različno razumljena. Pojasnjujejo njune začetke, pri čemer ima pomembno vlogo Edward Bernays s svojo Propagando in razvojem pojma odnosov z javnostmi v nadaljevanju. Oba sta bila namreč skozi zgodovino tesno povezana z varnostnimi, obrambnimi in vojaškimi vsebinami in še vedno je tako. Ta povezava je zelo podrobno pojasnjena skozi razlago uporabljene terminologije in njenih odtenkov. Eden od teh je tudi raba pojma strateško komuniciranje na področju državne uprave, medtem ko v gospodarstvu pretežno uporabljajo pojem korporativno komuniciranje. V novejših časih poudarjajo sicer že star, a povečan interes na področju komuniciranja $\mathrm{v}$ kontekstu vojaške in nacionalne moči. Te vsebine navadno niso priljubljene $\mathrm{v}$ javnosti, še zlasti, kadar gre za novo orožje, pri katerem gre za velik odvračalni učinek in temu primerno kolateralno škodo, kar pa zahteva več spretnosti in veščin pri njihovem komuniciranju. Zato se zdi logično, da za očeta začetkov komuniciranja velja ravno Bernays, ki je svoje veščine najbolj razvil po drugi svetovni vojni z več različnimi programi ameriške pomoči stari celini Evropi.

Nekaj pozornosti je namenjeno tudi izrazu strateško, kaj je torej strateško in kaj ne na področju komuniciranja.

Posebna izdaja International Journal of Strategic Communication z naslovom Future Directions of Strategic Communicaton je namenjena poznavalcem področja strateškega komuniciranja. Priporočamo jo akademikom in strokovnjakom, ki se kakor koli srečujejo s strateškim komuniciranjem, še posebej tistim, ki delajo na tem področju v varnostnih, obrambnih ali vojaških strukturah in si želijo v prihodnje narediti nekaj več. Kakovostna teorija in odlične praktične izkušnje so najboljša kombinacija za razvoj novih teorij, konceptov in idej. 